\title{
Petrographic Analysis and Correlation of Volcanic Rocks in Bostic 1-A Well near Mountain Home, Idaho
}

\author{
Barbara H. Arney \\ Jamie N. Gardner \\ Stephen G. Belluomini*
}

\section{DISCLAIMER}

\begin{abstract}
This report was prepared as an account of work sponsored by an agency of the United States Government. Neither the United States Government nor any agency thereof, nor any of their employees, makes any warranty, express or implied, or assumes any legal liability or responsibility for the accuracy, completeness, or usefulness of any information, apparatus, product, or process disclosed, or represents that its use would not infringe privately owned rights. Reference herein to any specific commercial product, process, or service by trade name, trademark, manufacturer, or otherwise does not necessarily constitute or imply its endorsement, recommendation, or favoring by the United States Government or any agency thereof. The views and opinions of authors expressed herein do not necessarily state or reflect those of the United States Government or any agency thereof.
\end{abstract}

*Harding-Lawson Ássociates, 7655 Redwood Boulevard, P.O. Box 578, Novato, CA 94947. 


\section{DISCLAIMER}

This report was prepared as an account of work sponsored by an agency of the United States Government. Neither the United States Government nor any agency Thereof, nor any of their employees, makes any warranty, express or implied, or assumes any legal liability or responsibility for the accuracy, completeness, or usefulness of any information, apparatus, product, or process disclosed, or represents that its use would not infringe privately owned rights. Reference herein to any specific commercial product, process, or service by trade name, trademark, manufacturer, or otherwise does not necessarily constitute or imply its endorsement, recommendation, or favoring by the United States Government or any agency thereof. The views and opinions of authors expressed herein do not necessarily state or reflect those of the United States Government or any agency thereof. 


\section{DISCLAIMER}

Portions of this document may be illegible in electronic image products. Images are produced from the best available original document. 
PETROGRAPHIC ANALYSIS AND CORRELATION OF VOLCANIC ROCKS IN BOSTIC 1-A WELL NEAR MOUNTAIN HOME, IDAHO

by

Barbara H. Arney, Jamie N. Gardner, and Stephen G. Belluomini

\section{ABSTRACT}

Detailed examination of volcanic rock cuttings from the Bostic 1-A well near Mountain Home, Idaho, provides data that correlate the stratigraphy of the well with the regional stratigraphy of the western Snake River Plain. The Bostic 1-A well penetrates basalt of the Middle Pleistocene Bruneau Formation and underlying sedimentary rocks of the Upper Pliocene Glenns Ferry Formation. Basalt underlying the Glenns Ferry Formation is most likely Banbury Basalt of Middle Pliocene age or Banbury equivalent. A $350-\mathrm{ft}$ interval of felsic volcanics is then intersected above another $600 \mathrm{ft}$ of basalt. The well bottoms in altered felsic volcanics.

The lowest $600 \mathrm{ft}$ of basalt flows has not been correlated with any basalt observed on the surface. From the established stratigraphy of the region, and from petrographic evidence, the silicic volcanic rocks occurring both above and below the lowermost basalts in the well are probably lower Pliocene Idavada Volcanics. North of the well, in the Mt. Bennett Hills, Idavada Volcanics overlie crystalline rocks of the Idaho batholith. No estimate of depth to plutonic bedrock can be made from the well data alone. Stratigraphic comparisons suggest as little as 0.2 to $0.3 \mathrm{~km}$ more of Idavada lie beneath the Bostic 1-A wel1. Results of geophysical studies suggest additional basalt lies beneath the Bostic 1-A rather than granitic rocks of the batholith.

\section{INTRODUCTION}

The Bostic 1-A well, on the northern margin of the Snake River Plain near Mountain Home, Idaho (T4S, R8E, S25) (Fig. 1) was drilled as an oil and gas wildcat to $2950 \mathrm{~m}(9676 \mathrm{ft})$ by Al Griffith in 1973. In 1974 Gulf Mịneral Resources $C_{0}$. took over the well as a geothermal prospect and ran additional lithologic and geophysical logs. In early 1978 the well was acquired by Union 0 il Co., who attempted to clean it out, then plugged and abandoned it in October 1978 . 
When the area east of Mountain Home, Idaho, was selected for study as a potential hot dry rock (HDR) geothermal site (Arney et al. 1982), a study of the Bostic 1-A cuttings was begun. The study revealed that the well in fact bottomed in silicic volcanics of the Idavada Formation rather than granite as previously reported (Gulf Mineral Resources Co., lithologic log). Believing that Idaho Batholith lay beneath the silicic volcanics, as indeed it does just north of the HDR prospect (Malde et al. 1963), we studied, in more detail, the volcanic stratigraphy in the well to estimate the depth to granite. The results of that work are presented in this report.

Subsequent gravity modeling suggests that no granite lies beneath the silicic volcanics at the Bostic location. Instead, rocks beneath the bottom of the Bostic 1-A well are interpreted to be basalts approximately $3 \mathrm{~km}$ thick, probably associated with the opening of the Snake River Plain (Arney et al. $1982)$.

\section{PROCEDURES}

Well cuttings were examined with a binocular microscope (Appendix A). Samples were taken at $9-\mathrm{m}(30-\mathrm{ft})$ intervals from depths of 426 to $536 \mathrm{~m}(1405$ to $1769 \mathrm{ft})$, and at $3-\mathrm{m}(10-\mathrm{ft})$ intervals from 1219 to $2949 \mathrm{~m}$ (4023 to 9676 $\mathrm{ft}$ ). The small size of the well cuttings and their fine grain size hindered mineral identification in some samples. Cuttings below $1768 \mathrm{~m}(5800 \mathrm{ft})$ were mounted on poster board (Fig. 2) at $0.5 \mathrm{in} .=10 \mathrm{ft}$ to allow a better understanding of the lower volcanic sequence. Detailed petrographic study was performed only on cuttings of the volcanic rock units. Grain mounts prepared of samples from depths between 1239 and $2949 \mathrm{~m}$ (4090 to $9676 \mathrm{ft}$ ) were examined with a petrographic microscope to identify formation and rock types (Appendix B).

To aid in correlation with mapped surface units of the Idavada Volcanics, representative intervals from each visually distinct silicic unit in the cuttings were chemically analyzed using $x$-ray fluorescence (XRF), following the method of Hagan (1982). Cuttings from these intervals were hand-picked, and thin sections made from the hand-picked samples were examined petrographically.

To identify the alteration minerals present, selected samples were also analyzed by $x$-ray diffraction (XRD) on $\leq 400$ mesh powders. When peaks of the alteration minerals were obscured by the original mineralogy, an additional 

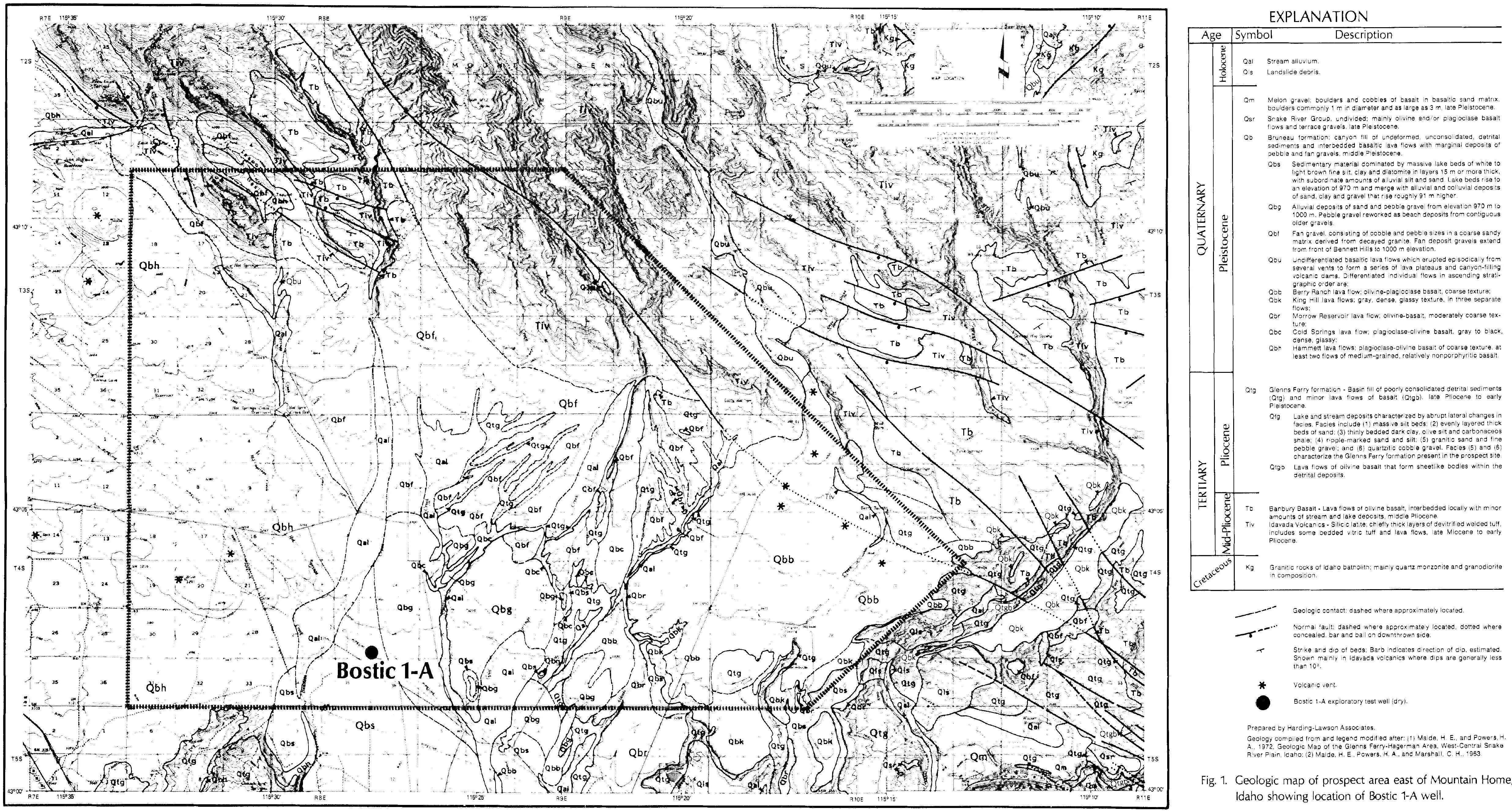

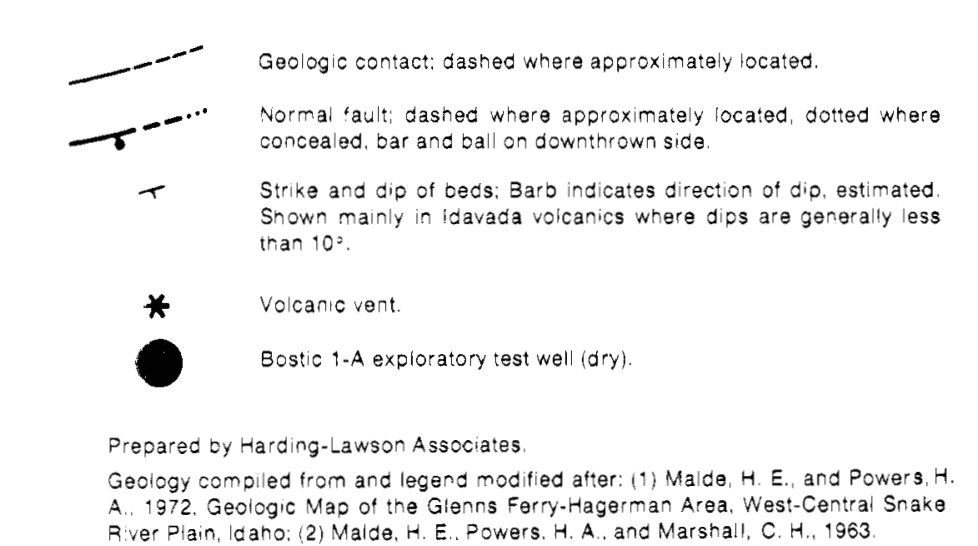

Fig. 1. Ceologic map of prospect area east of Mountain Home, Idaho showing location of Bostic 1-A well. 

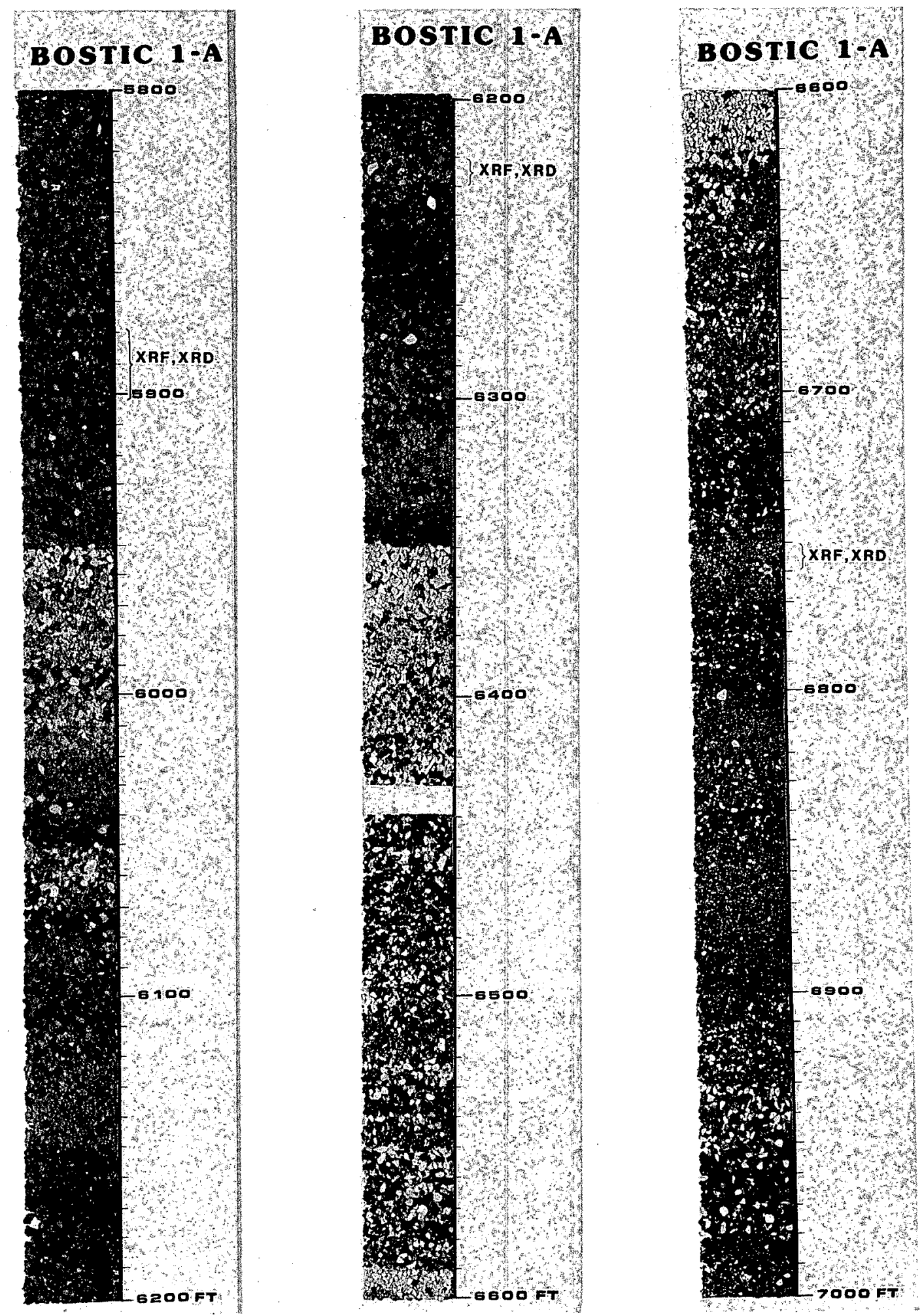

Fig. 2 .

Cuttings boards of the Bostic 1-A cuttings from 5800 to $9676 \mathrm{ft}$, XRF and XRD sampling intervals indicated. 

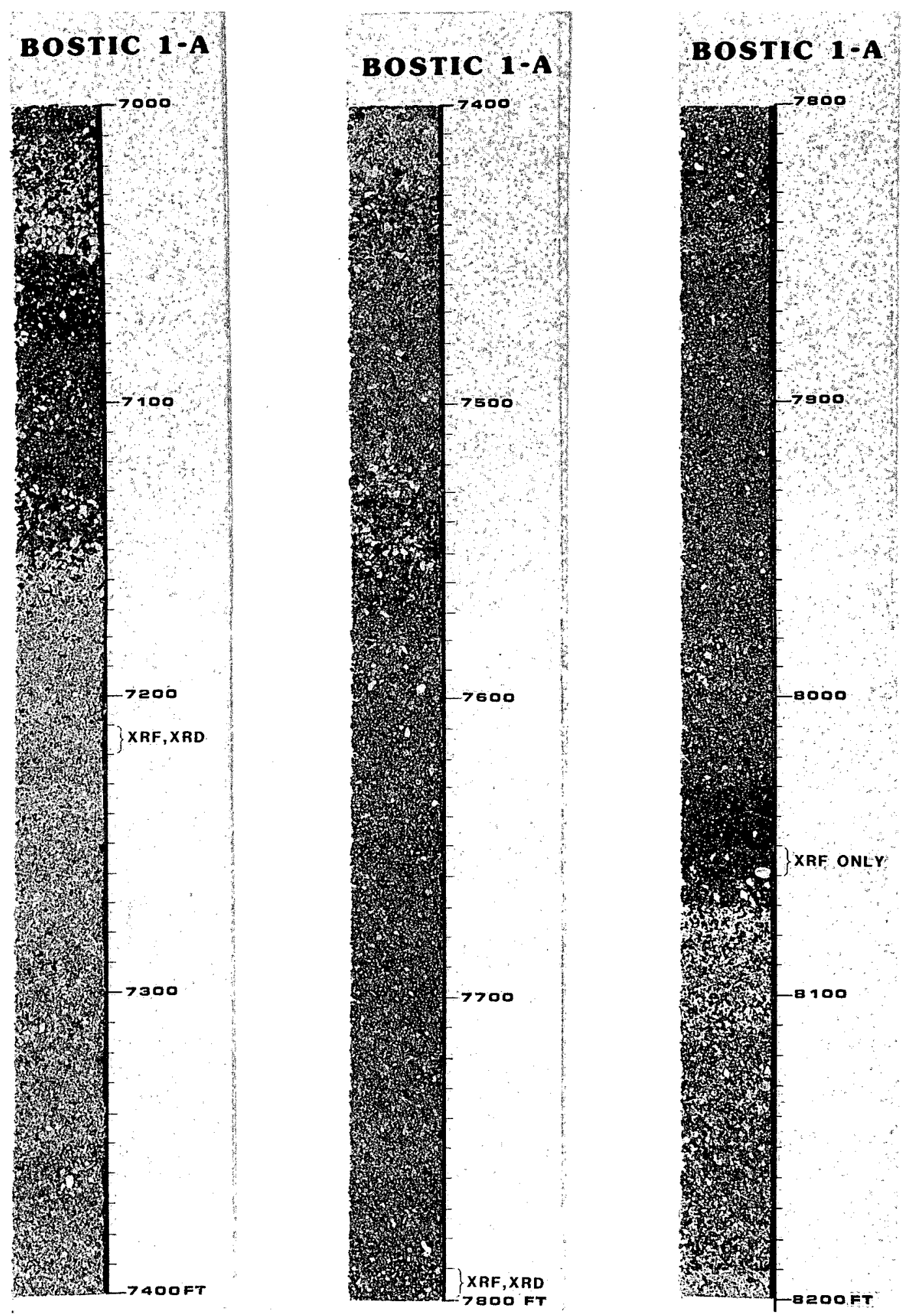

Fig. 2. (cont) 

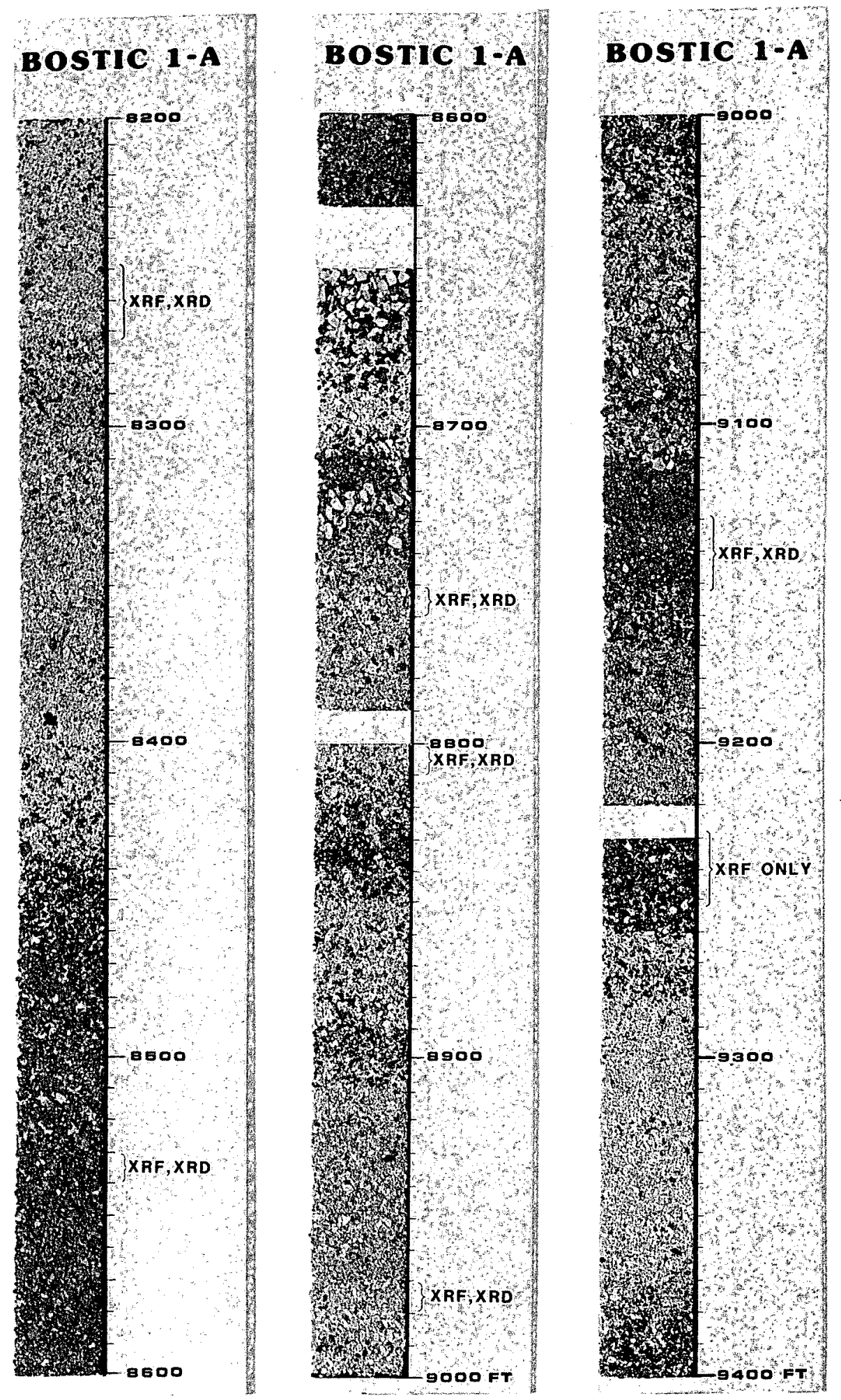

BOSTIC IA

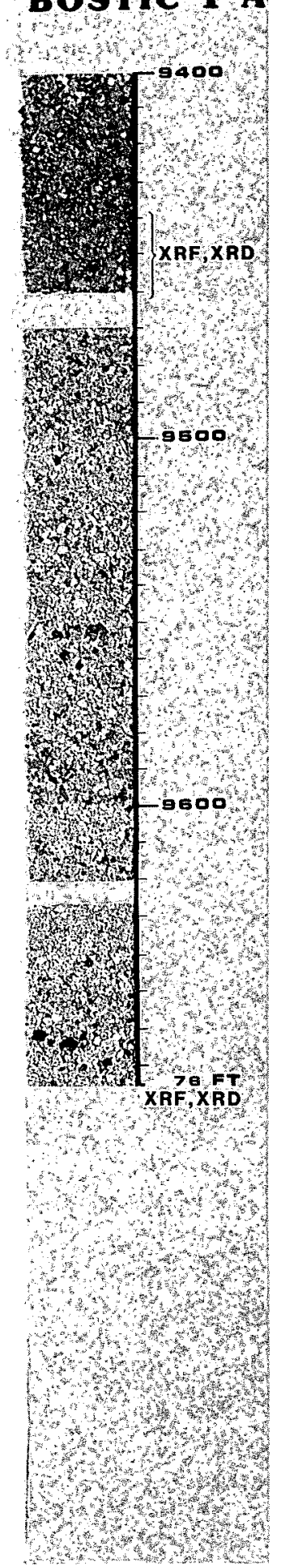

Fig. 2. (cont) 
hand-picked sample of highly altered cuttings from the same interval was powdered for XRD. These samples are indicated by "A" (alteration) following the interval depth numbers in Table C-III.

Altered basalt intervals, chosen for further study of alteration as a function of depth in the well, are commonly characterized by zeolite-filled amygdules and/or veins. The least altered fragments from each selected interval were hand-picked for XRF analysis. Two additional intervals believed to be dikes by their apparent freshness were also analyzed by XRF. Sampling intervals are indicated in Fig. 2.

Appendix $A$ is a lithologic description of well cuttings examined with a binocular microscope. Appendix B contains petrographic descriptions of grain mounts. Cuttings samples were taken at $10-\mathrm{ft}$ intervals, thus, feet are retained as the unit of measure in both Appendix $A$ and $B$. Appendix $C$ gives the results of XRD and XRF analyses.

\section{SUMMARY OF BOSTIC 1-A STRATIGRAPHY}

The summary of Bostic 1-A lithology is shown in Table I and Fig. 3 and focusses on lithologic features used for stratigraphic correlations. Hydrothermal alteration is pervasive below $1525 \mathrm{~m}(5000 \mathrm{ft})$, and ranges in severity with increasing depth from zeolite to greenschist facies. It is described in more detail in Arney, 1982.

\section{STRATIGRAPHIC CORRELATIONS}

Stratigraphic correlations are shown in Fig. 3. The upper $536 \mathrm{~m}$ (1769 $\mathrm{ft}$ ) of the well penetrates Bruneau Formation of middle Pleistocene age. Underlying the Bruneau Formation are sedimentary rocks of the Upper Pliocene Glenns Ferry Formation. The interval from 1219 to $1463 \mathrm{~m}(4000$ to $4800 \mathrm{ft}$ ) consists of basalt flows equivalent to the Banbury Basalt of middle Pliocene age. Basalts from the interval 1829 to $2179 \mathrm{~m}(6000$ to $7150 \mathrm{ft})$ are petrographically similar to those from 1219 to $1463 \mathrm{~m}(4000$ to $4800 \mathrm{ft}$ ) and are correlated to the Banbury Basalt. Malde and Powers (1962) and Malde et al. (1963) report the Banbury Basalt contains a $122-\mathrm{m}$-thick $(400 \mathrm{ft})$ lower unit of altered olivine basalt, which is separated from a 152-m-thick (500 ft) upper unit of olivine basalt and plagioclase-olivine porphyritic basalt by $30 \mathrm{~m}(100$ $f t)$ of sedimentary rock. Petrographic studies of the basalt cuttings from the 1219- to $1463-m$ interval (4000- to $4800-f t)$ reveal only minor amounts of 
TABLE I

DEPTH INTERVALS AND PRINCIPAL LITHOLOGIES PENETRATED IN BOSTIC 1-A WELL

- 0 to $213 \mathrm{~m}(0$ to $700 \mathrm{ft})$ : Not sampled during drilling; it probably consists of alluvium underlain by shale with thin interbedded clayey sandstone and siltstone.

- 213 to $417 \mathrm{~m}(700$ to $1400 \mathrm{ft})$ : Light gray clayey shale with thin sandstone and siltstone interbeds to $350-\mathrm{m}(1155-\mathrm{ft})$ depth, sandstone to $381 \mathrm{~m}(1257 \mathrm{ft})$, and basalt to $427 \mathrm{~m}(1410 \mathrm{ft})$. Information from Gulf Energy Minerals Co. lithology log.

- 427 to $536 \mathrm{~m}$ (1400 to $1730 \mathrm{ft}$ ): Mostly dark brown and black aphanitic to microporphyritic basalt. 1 to $2 \mathrm{~mm}$ zeolite-filled amygdules occur between 463 and $509 \mathrm{~m}(1520$ to $1670 \mathrm{ft})$.

- 536 to $1219 \mathrm{~m}$ (1760 to $4000 \mathrm{ft})$ : Mainly sandstone and shale, minor amounts of carbonate and pyrite. Minor basalt. Information from $A 1$ Griffith's lithology log.

- 1219 to $1463 \mathrm{~m}(4000$ to $4800 \mathrm{ft})$ : Basalt flows of intersertal to subophitic texture with minor amounts of olivine. Exceedingly finegrained basalt with variolitic texture, present in the interval from 1247 to $1250 \mathrm{~m}(4090$ to $4100 \mathrm{ft})$, is interpreted to be fragments of pillows. Pillow basalts are mentioned by Malde and Powers (1962) and Malde et al. (1963) only in their descriptions of Bruneau and Snake River basalts.

- 1463 to $1829 \mathrm{~m} \mathrm{(4800} \mathrm{to} 6000 \mathrm{ft}$ ): Mostly shale with some interbedded sandstone, claystone, and basalt. Information from Al Griffith's li thology $\log$.

- 1829 to $2179 \mathrm{~m}(6000$ to $7150 \mathrm{ft})$ : Basalt and interbedded sediments, mostly siltstone. Only the basaltic intervals were examined in detail. Except for an increase in alteration, the basalts in this interval are petrographically very similar to those in the 1219- to $1463-\mathrm{m}$ interval (4000 to $4800 \mathrm{ft}$ ). Three kinds are present: coarsegrained basalt with subophitic texture and only minor olivine (Type I), variolitic basalt with quench textures (Type II), and glassy plagioclase porphyritic basalt (Type III). The Types II and III basalts are interpreted to be pillow fragments and glassy flow tops.

- 2179 to $2265 \mathrm{~m}(7150$ to $7430 \mathrm{ft})$ : Fine-grained silicic tuff containing phenocrysts of plagioclase, potassium feldspar, magnetite, and pseudomorphs of chlorite after pyroxene.

- 2265 to $2460 \mathrm{~m}(7430$ to $8070 \mathrm{ft})$ : Basalt similar to that in 1829 - to 2179-m interval.

- 2460 to $2949 \mathrm{~m}$ (8070 to $9676 \mathrm{ft}$ ): These cuttings consist primarily of hydrothermally altered silicic tuffs. The few thin fresh basalt intervals are interpreted as dikes. 


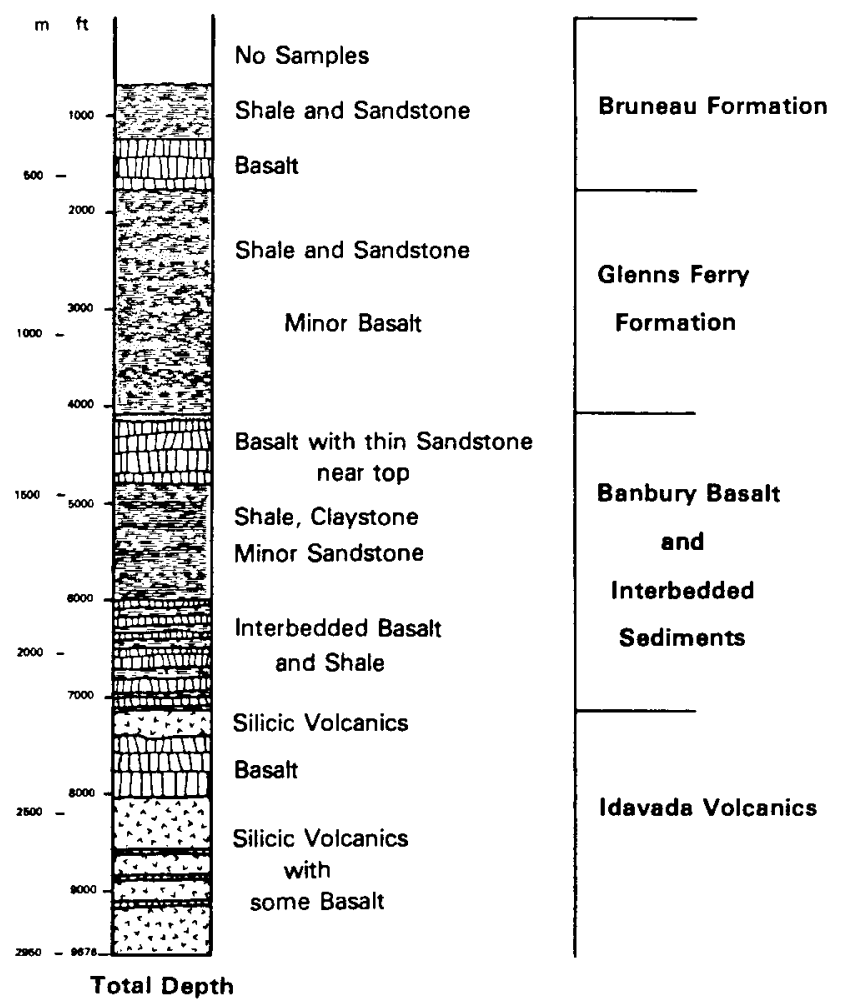

Fig. 3 .

Bostic 1-A 1ithology log.

olivine and it is not a dominant phenocryst phase. The sedimentary sequence between the upper and lower Banbury basalts observed in the well also appears to be thicker than that described by Malde and Powers. Hydrothermally altered cataclastic basalt fragments in the cuttings at $1295 \mathrm{~m}(4250 \mathrm{ft}$ ) suggest the well intersects at least one fault zone.

The silicic rocks at depths of 2179 to $2949 \mathrm{~m}(7150$ to $9676 \mathrm{ft})$ are interpreted as part of the Lower Pliocene Idavada Volcanics (see below), which are exposed in the Mt. Bennett Hills $11 \mathrm{~km}$ northeast of the well (Fig. 1). A schematic cross-section through the Bostic $1-A$ well is shown in Fig. 4.

\section{DISCUSSION}

Two questions arise concerning the silicic volcanics in the Bostic $1-A$ well. The first regards Challis Volcanics: Is Challis encountered in the well, and if not, does it underlie Idavada beneath the well?

Malde et al. (1963) distinguish Idavada from Challis by the absence of quartz, sanidine, biotite, and hornblende in the Idavada. Our work indicates that, while still separable from the challis by the absence of hornblende and biotite, the Idavada volcanics generally contain plagioclase, two pyroxenes, 


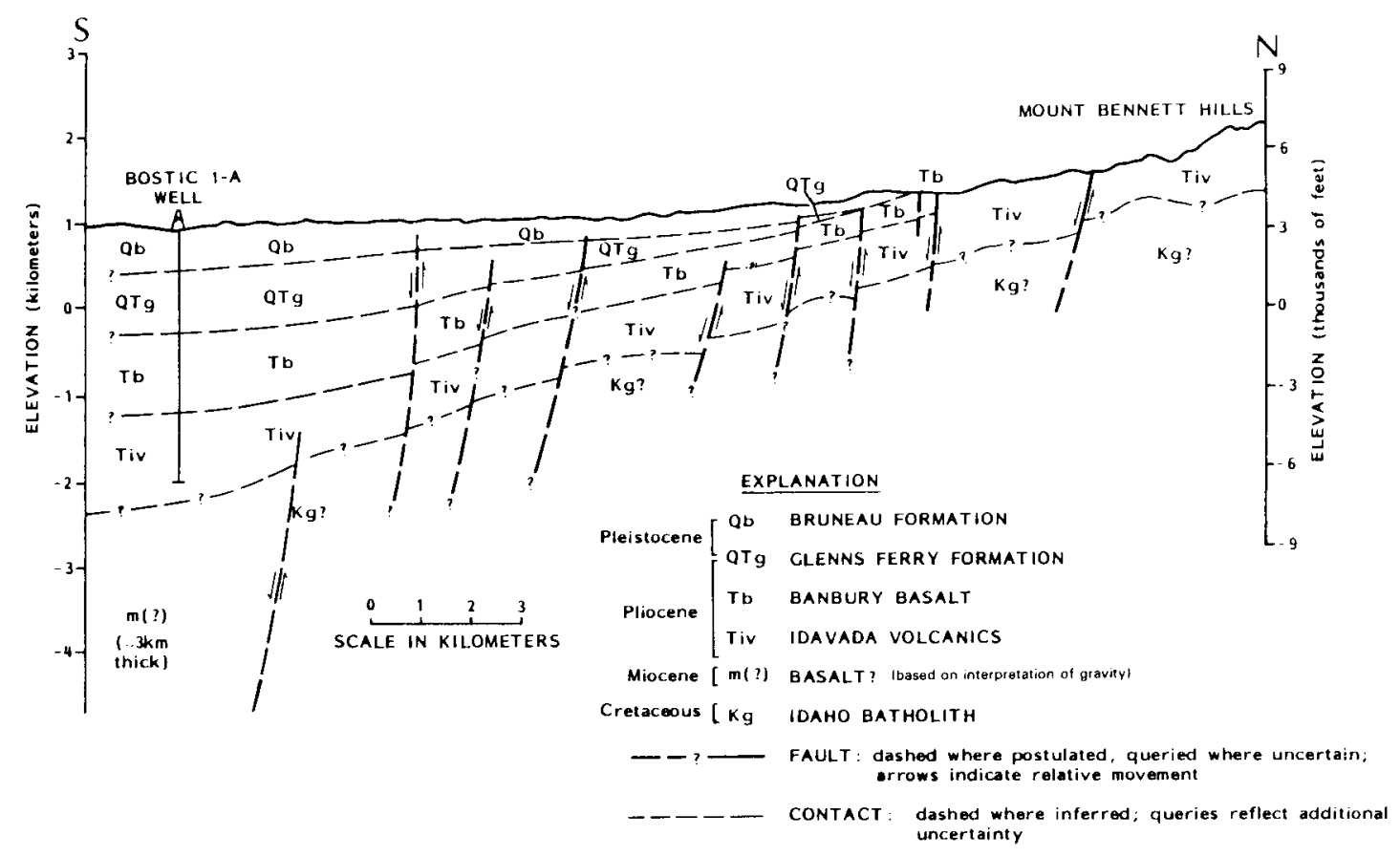

Fig. 4 .

Schematic cross-section through the Bostic 1-A well and the prospect area near Mt. Home, Idaho (from Arney et al. 1981).

olivine, K-feldspar, magnetite, and ragged, embayed quartz. Challis volcanics contain quartz, sanidine, and biotite in rhyolites, and plagioclase and hornblende in andesites.

Mafic minerals in the silicic volcanics penetrated by the Bostic well have rarely survived hydrothermal alteration. Pseudomorphs of chlorite and magnetite \pm serpentine after pyroxene and olivine occur in several intervals. No hornblende, biotite, or biotite pseudomorphs were found in any of the silicic volcanic cuttings; therefore challis Volcanics were not penetrated by the well.

North of the prospect area, along U.S. Highway 20, Challis Volcanics underlie the Idavada volcanics and separate them from the Idaho Batholith. The Challis Volcanics thin dramatically farther west and pinch out altogether to the south towards the prospect area (Gardner and Wood, in prep.). Although it is not possible to say from well data alone whether or not challis Volcanics underlie Idavada beneath the well, regional geological mapping of the Challis suggests that they do not (Malde et al. 1963; Gardner and Wood, in prep.). 
The second question concerning the silicic volcanics is whether all the silicic rocks are Idavada, even though there is a thick basalt sequence from 2265 - to $2460-\mathrm{m}$ depth $(7430$ to $8070 \mathrm{ft})$.

Geologic maps (Malde et al. 1963; J. Gardner and S. Wood, Los Alamos National Laboratory, in prep.), show Banbury Basalt overlying the Lower Pliocene Idavada Volcanics in nearby areas (Fig. 1). East of the prospect area, the Banbury and Idavada are locally separated by up to $152 \mathrm{~m}(500 \mathrm{ft})$ of densely welded quartz and sanidine phyric rhyolite tuff of Lower Pliocene age, termed the Rhyolite of Magic Reservoir (Malde et al. 1963), but no basalt lies between this rhyolite and the underlying Idavada Volcanics.

Malde and Powers (1962) describe basalts underlying and intertonguing with Challis equivalents (Miocene age rhyolites) in the Owyhee and Jarbidge Mountains $80-100 \mathrm{~km}(50-75 \mathrm{mi})$ west of the prospect area. Smith (1966) reports diktytaxitic olivine basalts intercalated with Idavada northeast of the Bostic well in the eastern Mt. Bennett Hills.

Although basalts are commonly interbedded with silicic volcanic rocks on the margins of the Western Snake River Plain, none of the reported occurrences indicate such thick basalt intervals as seen in the Bostic well, and no interbedding of basalts with Idavada volcanics was mapped in the western Mt. Bennett Hills by Gardner and Wood (in prep.).

Idavada Volcanics in the Mt. Bennett Hills were erupted during the faulting associated with the opening of the Snake River Plain (Gardner and Wood, in prep.), and the areal extent of each unit is determined by the topography onto which they were erupted (Smith 1966; Gardner and Wood, in prep.). Since the thick basalts seen in the well occur in the upper part of the Idavada, they may have been confined to the lowlands by down-faulting along the margins of the plain and therefore are not seen in the uplifted Mt. Bennett Hills section.

It was not possible to correlate various flow units of the Idavada Volcanics as mapped on the surface with specific intervals within the well. The chemistry of the surface units does not vary enough to make them distinctive, and variations in phenocryst content and composition were obliterated in the cuttings by the high degree of alteration. Descriptions in this report, compared to the structural and stratigraphic data of Gardner and Wood (in prep.), suggest there may be as little as 0.2 to $0.3 \mathrm{~km}$ more of Idavada beneath the Bostic 1-A well. 
Idaho Batholith rocks occur only as fragments in sedimentary horizons in the wel1. Depth to in situ granitic rocks below the Bostic is not possible to evaluate based on our data. Geophysical modeling reported in Arney et al. (1982) suggests a great thickness of basalt beneath the Bostic well, and that probably no granitic rocks of the Idaho Batholith underlie this portion of the Snake River Plain.

\section{REFERENCES}

Arney, B., "Evidence of Former Higher Temperatures from Alteration Minerals, Bostic 1-A Wel1, Mountain Home, Idaho," GRC Trans, 6- pp. 3-6 (1982).

Arney, B. H., F. E. Goff, and Harding-Lawson Associates, "Evaluation of the Hot Dry Rock Geothermal Potential of an Area Near Mountain Home, Idaho," Los Alamos National Laboratory report LA-9365-HDR (May 1981).

Gardner, J. N. and S. H. Wood, "Geologic Map of the Bennett Mountain Area, Elmore County, Idaho," Los Alamos National Laboratory map, scale 1:62,500 (in preparation).

Hagan, R. C., "X-ray Fluorescence Analysis Major Elements in Silicic Minerals," Los Alamos National Laboratory report LA-9400-MS (September 1982).

Malde, H. E. and H. A. Powers, "Geologic Map of the Glenns Ferry-Hagerman Area, West-central Snake River Plain, Idaho," US Geol. Surv., Misc. Geol. Invest. Map No. I-696, Scale 1:48 000 (1972).

Malde, H. E. and H. A. Powers, "Upper Cenozoic Stratigraphy of Western Snake River Plain, Idaho," Geol. Soc. Am. Bul1. 73, 1197-1220 (1962).

Malde, H. E., H. A. Powers, and C. H. Marshall, "Reconnaissance Geologic Map of the West-central Snake River Plain, Idaho," U.S. Geol. Surv. Misc. Geological Investigation Map I-373, scale 1:125,000 (1963).

Smith, C. L., "Geology of Eastern Mt. Bennett Hills, Camas, Gooding, and Lincoln Counties, Idaho, Ph.D. thesis, Univ. of Idaho, 129 pp. (1966). 
APPENDIX A

BINOCULAR MICROSCOPE EXAMINATION

(portions of interval 1400-5800 ft modified from Belluomini and Van Houten, 1981)

Interval*

$(\mathrm{ft})$

$1400-1760$ minor clasts of tan claystone, and quartz crystals occur. The basalt is fresh, black, and the groundmass varies from aphanitic to glassy (a reddish-black resinous glass). Scattered minute $(1 \mathrm{~mm})$ plagioclase laths, plagioclase clots, and rare olivine(?) are present. About $70 \%$ of the basalt cuttings between $1520-1670 \mathrm{ft}$ are dark brown and appear to be coated with soil. Small (1-2 mm) zeolite-filled amygdules also occur.

1760-4090 Interval not examined. Primarily sedimentary with minor basalts, correlated with Glenns Ferry Formation. Information from Griffith's lithology log.

4090-4760 Cuttings are mostly glassy to aphanitic basalt. 5-20\% of the cuttings are weakly to moderately calcareous tan claystone, and up to $5 \%$ are clear quartz crystals. Minor constituents, $10-2 \%$ in individual samples), include tarnished biotite flakes, muscovite flakes, and unusual cataclastic basalts. These deformed basalt fragments resemble sheared fine-grained plutonic rocks. (They are more completely described in Appendix B, Sample 4240-4250 ft). A11 components except basalt decrease rapidly below $4000 \mathrm{ft}$ and by 4400 $\mathrm{ft}$ the cuttings are almost totally basalt. The basalt becomes coarser-grained with depth.

*Original well logs (reproduced in Fig. A-1(a-e) in pocket on inside back cover) were recorded in feet. This Appendix will maintain that notation. For intervals above $5800 \mathrm{ft} 1$ ithologic breaks are based on drillers' lith log and dual induction $\mathrm{log}$. Lag is insignificant. Below $5800 \mathrm{ft}$ lithologic breaks are based on cuttings depths not corrected for lag. Lithologic log in Fig. A-1 is not corrected for lag so depths below $5800 \mathrm{ft}$ do not correspond exactly to those on geophysical logs. Descriptions in this appendix are based on a more detailed study of the cuttings and differ slightiy from those on the lithology $\log$ in $\mathrm{Fig}$. A-1. 
Unusual features of individual samples from this interval are:

4240-4250 5-10\% cataclastic basalt fragments

$4250-4260 \quad 2-5 \%$ quartz and muscovite crystals

4470-4480 One fragment of a zeolite-filled amygdule

4680-4690 and 4700-4710 One percent of the basalt fragments are coated with sugary green opal(?).

4760-5800 Not examined. Primarily sedimentary with some basalt interpreted as interbedded sediments of Banbury Basalt. Information from Al Griffith's drillers log.

5800-7150 (7125 ft on electric logs, lag correction would make cuttings depth $7140 \mathrm{ft})$. Basalt with interbedded sediments. Apparently several flows separated by sedimentary intervals. The interior of each flow is altered and zeolitized, but the tops and bottoms are generally fresher.

5800-5950 Basalt with plagioclase and pyroxene phenocrysts. Altered, contains zeolites and/or calcite. Rounded cuttings appear brownish and soil covered. Base of unit is fine-grained, blue-gray basalt.

5950-6040 Sedimentary layer, upper part is coarse-grained and cuttings look like altered granite, but thin section shows them to be wacke consisting of quartz and altered feldspar in a pale greenish gray clay matrix. With greater depth, fine-grained volcanics, basalt, and a finer grained variety of the green wacke appear.

6040-6050 Fresh glassy basalt - possibly a dike.

6050-6070 Siltstone, mixed with fine-grained basalts.

6070-6350 Several basalt flows. Vary from very black coarsegrained fresh rock, to altered gray-green or oxidized red rocks with zeolites and green clays(?).

6350-6620 Top and bottom of this interval are siltstones, and siltstone comprises at least $30 \%$ of cuttings throughout the interval. Beneath the upper siltstone is a finegrained green wacke, similar to that at $5950 \mathrm{ft}$. Coarse-grained, fresh, black, basalt cuttings appear below the wacke. Basalt is mixed with siltstone and 
lost circulation materials and so is not a clearly defined unit.

6620-7150 Basalt flows with thin sedimentary interbeds. Thickest sedimentary bed is siltstone between 7020-7050 ft. Red argillite appears between 7100 and $7130 \mathrm{ft}$. Basalt varies from very fresh black and coarse-grained with abundant tiny feldspar laths, to altered, zeolitized, reddish, or green-gray.

7150-7420 (7380 ft on electric logs, lag correction for cuttings would make $7400 \mathrm{ft}$ ). Pale lavender-gray aphanitic silicic tuff with sparse phenocrysts of feldspar and dark green chlorite after pyroxene(?). Top $20 \mathrm{ft}$ are altered chalky green. Red staining and mottling increases with depth. Some brick-red fragments. Green clay appears toward base of unit. At 7230-7240 ft abundant calcite and/or zeolite, matrix totally altered brick red.

7420-7460 Dark gray aphanitic silicic tuff, and increasing amounts of basalt. At 7430-7440 ft fresh dark black plagioclase phyric basalt. Below 7440, plagioclase is smaller but more distinct because basalt is so altered. Mostly red, with zeolite-filled amygdules.

7460-8070 Mostly basalt with one possible sedimentary interval $(7520-7570 \mathrm{ft})$ which contains siltstone, dark brown shale and abundant drill pipe fragments. No indication on $\log$ of change in drilling, circulation or electrical properties over that interval. Basalt is altered; greenish plagioclase laths in a reddish matrix become greenish plagioclase laths and green clay in a purplish matrix with increasing depth. Zeolite amygdule fillings scattered throughout. Abundant zeolites at 7790-7810,7830-7850, and 7870-7880 ft.

Basalt at base of interval $(8030-8070 \mathrm{ft})$, is fresh and black and appears almost glassy from the intergrowth of fresh pyroxene and plagioclase. Interpreted as dike because of the lack of alteration.

8070-8080 Altered silicic tuff with abundant quartz, and chalky feldspar. Some terminated quartz crystals up to $2 \mathrm{~mm}$ long.

8080-8190 Very fine-grained, dark red to medium gray to pale pink, baked claystone or shale comprise $30-40 \%$ of the cuttings. Interval also includes cuttings of basalt, plagioclase porphyritic pale green silicic tuff, siltstone, and minor zeolites and quartz. 
8190-8430 Silicic tuff, mostly pale green aphanitic matrix, but with plagiociase and abundant magnetite in crystal clusters up to $1 \mathrm{~mm}$ in diameter. Green clay alteration increases with depth. Green fluorite(?) veins and fillings above $8300 \mathrm{ft}$. Fragments of light pink to red claystone appear at 8270-8290 ft. Yellow-green (mostly euhedral) epidote crystals first appear at 8390-8400 ft. Traces of epidote coatings appear as high as $8260 \mathrm{ft}$. A few fragments of dark red-brown vitrophyre with clear feldspar crystals appear at 8430 feet.

8430-8630 (8380-8605 on gamma log) Fine-grained dark gray basalt with zeolites and minor epidote. Siltstone fragments at $8510-8530 \mathrm{ft}$ may be from a thin sediment interbed or may be downhole contaminants. Alteration of basalt to white plagioclase and green clay in a reddish matrix is most intense between 8510 and $8580 \mathrm{ft}$. Pink aphanitic (silicic?) volcanic rock comprises about half the cuttings at $8610-8620 \mathrm{ft}$, but the $10 \mathrm{ft}$ interval below this is basalt. No returns from 8630-8650 ft.

8650-8670 Predominantly siltstone with some basalt, altered silicic tuff, and vitrophyre.

8670-8710 Altered and silicified tuff, pale green and chalky-white. Salmoncolored staining is intense toward base of interval. Euhedral pyrite in the matrix. Chlorite pseudomorphs.

8710-8720 Fine-grained dark gray basalt.

8720-8730 Mostly siltstone, with some basalt tuff or minor vitrophyre.

8730-8820 t8780 on gamma log). Pale gray, green to lavender silicic tuff with fine veining. Pyrite occurs in small euhedral crystals. One fragment of massive pyrite in the $8730-8740 \mathrm{ft}$ interval. Salmon to red staining predominates down to $8780 \mathrm{ft}$, green clay or chlorite alteration to $8820 \mathrm{ft}$. Chalky white material occurs throughout interval (free and in green matrix). No epidote in this interval. Trace of green fluorite(?).

8820-8840 (8780-8801 on gamma log). Fresh fine-grained basalt, possibly dike. 8840-8890 Mostly white or very light green silicified tuff. Many fragments appear veined or brecciated. Minor disseminated pyrite.

8890-8900 Fresh fine-grained basalt as in 8820-8840 $\mathrm{ft}$. 
8900-8970 White to gray tuff, extremely altered and with salmon mottling. Silicified fine sugary appearance to grains. Minor disseminated pyrite and vein epidote.

8970-9110 Light green to gray silicified tuff. Light green color seems to be associated with fresh very fine grained magnetite-rich basalt, which comprises about $50 \%$ of interval $9000-9030 \mathrm{ft}$. Several fragments of siltstone at 9020-9030 ft. Both light green and darker gray tuff appear silicified and aphanitic. Magnetite is not as abundant as in $8190-8430 \mathrm{ft}$, but is nearly the only visible phenocryst(?). Minor disseminated pyrite and vein epidote.

9110-9150 Coarse, dark sage-green to gray basalt, some zeolite amygdule fillings at 9140-9150 ft.

9150-9220 Greenish gray tuff with sparse plagioclase phenocrysts. Some calcite veining. Euhedral crystals of quartz. Minor disseminated pyrite. Yellow-green epidote with quartz in euhedral crystals lining fractures at base of interval. No returns next $10 \mathrm{ft}$.

9230-9260 Mostly fresh fine-grained basalt with some tuff. Probably dike or sill intruded along fracture zone.

9260-9380 Pale green altered tuff. Phenocrysts barely discernible. Epidote occurs as veins and small crystalline patches in nearly every chip. Rare disseminated pyrite. Lowest $10-\mathrm{ft}$ interval is darker, redbrown stained, and shows brown-green alteration with small white chalky specks.

9380-9460 Mostly a dark gray aphanitic rock with plagioclase phenocrysts. Minor fresh fine-grained basalt at the top of the interval. Epidote occurs in lighter color grains that may be downhole contaminants. A few fragments of massive (pyrite?) sulfide.

9460-9470 No returns.

9470-9676 (TD) Light green-gray very altered tuff, lighter in color and chalky in appearance with depth. Epidote veins and coatings. Silvery (sulfide?) linings of many dissolution cavities, especially above $9550 \mathrm{ft}$. Several fragments of vitrophyre at $9550-9560 \mathrm{ft}$. Red-brown alteration of fragments at 9590-9600 ft. Rare disseminated pyrite. Quartz is probably secondary. A few altered feldspar phenocrysts occur. 


\section{REFERENCES}

Belluomini, S. G. and G. Van Houten, "Petrographic and Stratigraphic Correlation of the Bostic 1A Well," Harding-Lawson Associates report to Los Alamos National Laboratory (1981).

APPENDIX B

GRAIN-MOUNT PETROGRAPHY

(Some descriptions modified from Belluomini and Van Houten, 1981.)

Intervals selected for XRF analysis indicated by "(XRF)" in "Interval" column. (See "Procedures" for criteria for selection).

Interval

$(f t)$

Description

4090-4100 Ninety percent basalt, five percent claystone, rest individual crystals of plagioclase (plag), quartz (some show undualtory extinction), clinopyroxene (cpx), minor olivine (01), and a few fragments of palagonite. Claystone: Fragments are massive and composed predominantly of subequal amounts of exceedingly finegrained clay and fine angular to subrounded quartz grains with minor amounts of carbonate, opaques, and mafic minerals. Basalt: Cpx and plag with glass and minor ol. Texture mainly intersertal to subophitic, locally hyaloophitic or amygdaloidal (filled with clay and carbonate). Glass, $75 \%$ of which is palagonitized, is largely dark red to red-brown, rarely pale brown. Cpx is tancolored in plane-polarized light (PPL) and commonly zoned, sometimes in an hourglass pattern. 01 is either partially serpentinized or marginally altered to iddingsite. Opaques have a skeletal habit. Plag laths show very little or no zoning. Half a dozen fragments of exceedingly fine-grained basalt are also present with very long, narrow plag laths (1ength-to-width ratios of $10-$ 20:1) that are usually randomly oriented or locally show a weakly developed variolitic texture set in an altered groundmass of green clay and granular opaques.

4150-4160 Virtually identical to the above sample. 
4240-4250 Lithology and percentage of various components identical to the above two samples except for the addition of $5-10 \%$ hydrothermallyaltered cataclastic basalt and minor amounts of single crystals of oxybiotite, carbonate, and quartz. Also present are single crystals of $c p x$ and unoxidized biotite that show undulatory extinction and bent cleavage planes. Cataclastic basalt: Elongate fragments with a streaked fabric. Cpx completely granulated and generally totally converted to epidote. Plag has survived granulation much better than the $c p x$ and thus occurs as crudely developed augens with undulose extinction.

4400-4410 Very similar to the above samples. Tan color in cpx more prominent; a higher percent of the glass is palagonitized. Minute hopper crystals of plag occur in some of the palagonite.

4450-4470 Coarse-grained intersertal to subophitic fresh basalt. Stubby (XRF) plag stained yellow-brown along fractures, and pale tan cpx fractured along cleavage but unaltered, in a groundmass of brown palagonitized glass with skeletal plag and tiny magnetite. Opaque minerals are large blocky, some skeletal; magnetite and ilmenite. Sparse serpentinized ol crystals. Tiny acicular apatite inclusions in plag.

4540-4550 Almost totally basaltic. Differs from the above in having less original glass, slightly coarser grain size, and slightly more 01. One fragment of dark red-black glass with a single plag crystal.

4720-4730 Basalt noticeably fresher than above. Most glass fresh, and contains abundant apatite needles, plag hopper crystals, and minute plumose cpx crystallites.

5890-5900 Not a truly homogeneous sample. Predominantly ( $70 \%)$ devitrified (XRF) palagonitized glass, $30 \%$ fine- to medium-grained basalt.

6050-6060 Largely subophitic plagioclase phyric basalt with locally developed ophitic texture. Plag is fresh, cpx locally rimmed and/or veined with hematite, groundmass entirely palagonite, green clay, and/or dark-black, red-black glass (chlorophaeite?). Cpx strongly tancolored in plane-polarized light. Five percent claystone, as above, but slightly coarser grained and richer in carbonate. One percent total single crystals of plag, red-black glass containing scattered plag laths locally converted to clay(?), devitrified 
glass, and fragments of chilled basalt with weakly developed variolitic texture (see sample 4090-4200 ft).

6130-6140 Largely subophitic to intersertal pyroxene phyric (rarely ophitic) basalt with large amounts of clay in the groundmass and in amygdules. Minor development of zeolites in amygdules. Five percent total devitrified glass (spherulitic), single crystals of plag and cpx, black glass with varioles of green clay, and chilled, weakly variolitic basalt.

6220-6230 Homogeneous but very altered sample. Fine-grained to variolitic (XRF) basalt with plag phenocrysts and sparse ol relicts, now heavily outlined by opaques. Groundmass choked with tiny $(<0.02 \mathrm{~mm})$ opaques, rendering grains nearly opaque. Interstitial pyroxene $<0.01 \mathrm{~mm}$, and altered green glass. Some of the coarser plag has green clay replacement, and chlorite fills vesicles. Some grains have bright orange-red alteration of pyroxene and plag and serpentinized(?) 01 .

6250-6260 Basalt with minor claystone and devitrified glass. Lithologies as above. Basalt fragments locally peppered with equant opaques. No zeolites.

6320-6330 The bulk of this sample is composed of two types of basalt:

Type I - Subophitic plag phyric (as described in 6050-6060 interval).

Type II - Very long, narrow plagioclase laths usually set in a dark brown, nearly opaque groundmass.

The plag in Type II is often variolitic; a few hopper crystals are usually present. Some of the groundmass is altered to green clay and there are a few amygdaloidal zeolites. Cpx occurs only as minute granules. Approximately $2 \%$ devitrified glass (spherulitic) and traces of red-black vitrophyre with a few plag laths.

6370-6380 Seventy percent sedimentary, ranging from claystone (as above) to fine-grained sandstone with a clay matrix and angular quartz grains. Thirty percent basalt, both Type I and II (see above). Minor amounts of individual crystals of $\mathrm{cpx}$, carbonate, zeolites, serpentinized 01 , and devitrified glass.

6560-6570 Mixture of claystone and Type I and II basalts with trace amounts of devitrified glass and orange palagonite. The Type I basalt 
contains minor amounts of 01 and zeolites. Five percent basalt. fragments with fresh glass and skeletal opaques (similar to $4000-$ $4800 \mathrm{ft}$ ). This Type I basalt seems to grade into another type of basalt:

Type III - Dark red-black glass partially converted to green clay and enveloping cloudy plag laths, with minor cpx.

6630-6640 Largely Type I basalt with lesser amounts of Type III basalt and only minor amounts of Type II basalt, claystone, and devitrified glass. Type I basalt groundmass is largely dark red to red-black glass or chlorophaeite(?). It also contains abundant green clay and zeolites, and is locally veined with hematite.

6750-6760 Mixture of 30\% Type I, 20\% Type II, and 50\% Type III basalt. (XRF) Abundant zeolites in all three basalt types. The groundmass of the Type III basalt is almost opaque dark brown-black from oxidation and peppered with opaques. Trace amounts of cataclastic basalt. Hand-picked XRF sample: not homogeneous sample. Mostly ( $60 \%$ ) ophitic to subophitic basalt. Yellowish-brown alteration of pyroxene especially at edges of grain, some green clay replacing feldspar. Opaques are magnetite and ilmenite. $30 \%$ coarser grained plag in opaque glass matrix. One piece fine-grained siltstone. Vein chlorite, carbonate and quartz \pm feldspar.

6840-6850 Roughly equal amounts of Type I and II basalts and dark orangebrown palagonite; minor amounts of Type III basalt. Most palogonite contains plag laths and shows local relict perlitic cracks. Minor claystone.

6960-6970 Type I basalt twice as abundant as Type II. Minor amounts of marginally serpentinized ol in Type I. Some fragments have fresh glass. Minor amounts of claystone, devitrified glass, and orange palagonite.

7020-7030 Thirty percent carbonate-rich claystone, 25\% Type I basalt, and 40\% Type II basalt. Type I basalt groundmass has abundant clay and palagonite. Minor calcite crystals, zeolite, and Type III basalt.

7160-7170 Three to five percent total claystone and Type I basalt. Rest is devitrified tuff. Relict shards can be recognized in a few fragments. 
7210-7220 Tuff, original structure obliterated by devitrification. Homogene(XRF) ous sample. Phenocrysts of plag spottily replaced by albite or patches of carbonate, pyroxene altered to chlorite. Euhedral magnetite. Rare zircon.

7310-7320 Identical to 7160-7170 ft, except devitrified tuff contains pseudomorphs of chlorite and magnetite \pm serpentine after pyroxene and 01 (?).

7420-7430 Subequal amounts of devitrified tuff and basalt. Minor amounts of claystone and zeolite amygdules. Five percent very fresh basalt fragments with large ophitic cpx crystals.

7480-7490 Very similar to $7420-7430 \mathrm{ft}$. Alteration of basaltic groundmass more extensive. Felsic devitrification products coarser grained.

7600-7610 Ninety-five percent basalt of all three types. Five percent fresh basalt (as in $7420-7430 \mathrm{ft}$ ), traces of plag crystals, zeolite amygdules, and devitrified tuff.

7640-7650 Fifty percent Type I basalt with large amount of clay in both the groundmass and amygdules, some zeolite-filled amygdules. Fifteen percent fresh basalt, 10\% Type II basalt, 25\% devitrified tuff, locally spherulitic.

7790-7800 Five to ten percent total Type I basalt, chips of dark orange (XRF) palagonite, zeolites, devitrified tuff, and cataclastic basalt. Rest is largely Type III with a minor amount of Type II basalt. Type II has strongly developed variolitic plag and large amounts of clay in the groundmass. Type II basalt also contains a few $c p x$ granules, which are usually rimmed or veined with hematite. Handpicked XRF sample: fairly homogeneous coarse-grained basalt with intersertal texture. Some variolitic feldspar in opaque glass. Chlorite partially replacing glass and filling voids. Chlorite and minor epidote replacement of some feldspar. Serpentine pseudomorph after 01. Abundant opaques in some grains include magnetite and ilmenite, sparse opaques in others. Glass in many grains is opaque.

7890-7900 Seventy-five percent Type I basalt with small amounts of ol and 25\% Type III basalt. Minor amounts of carbonate-poor claystone; clayfilled amygdules, fresh basalt, devitrified tuff, and Type II basalt.

7990-8000 Virtually identical to 7890-7900 ft. Perhaps a bit more devitri- 
fied silicic volcanic (tuff?) and claystone.

8020-8030 Sixty percent Type I basalt with a clay-rich groundmass, 20\% Type III basalt, and 20\% carbonate-poor claystone. Minor amounts of devitrified silicic volcanic, Type II basalt, and clay-filled amygdules, some of which contain intergrown zeolites.

8030-8040 Mainly fresh subophitic basalt with some groundmass clay. Minor amounts of all three basalt types, devitrified silicic volcanic (locally spherulitic), and claystone.

8050-8060 Two basalt types. Predominantly ( $80 \%$ ) coarse-grained (0.5-1.0 (XRF) mal fresh subophitic to intersertal basalt. Sparse opaques are mostly blocky magnetite. Minor chlorite alteration of feldspar and pyroxene. Fragment of vein epidote. Rest of grains are opaque glass, most containing thin skeletal feldspar laths.

8070-8080 Sixty percent devitrified silicic volcanic with large relict crystals of embayed quartz and feldspar and minor alteration to epidote; rare granitic fragments exhibiting perthite; large free microcline crystals; $20 \%$ each of Type I and II basalt. Traces of claystone and opaque black glass (without crystals).

8240-8250 Five-ten percent basalt; subequal amounts of Type I and II. Rest is devitrified silicic volcanic; minute epidote is abundant in the groundmass.

8260-8270 Coarsely devitrified tuff. Original shard structure lost. Small (XRF) patches of brown clay and chlorite and minor epidote alteration in groundmass. Larger patches of carbonate replacement. Voids filled with chlorite \pm potassium feldspar and quartz. Plag phenocrysts are abundant and very altered. Rounded opaques are probably magnetite. No pseudomorphs after pyroxene or 01 . Rare sphene.

8430-8440 Seventy-five percent devitrified silicic volcanic (tuff) as in 8070-8080 ft, strongly epidotized. About 5\% of the fragments show evidence of relict welded textures; devitrified tuff also contains several blocky pseudomorphs of chlorite after pyroxene and 01; 20\% Type I and 5\% Type II basalt. Traces of calcareous claystone and opaque red-black glass.

8530-8540 Mostly homogeneous sample of medium-grained subophitic basalt with (XRF) abundant blocky magnetite $0.05 \mathrm{~mm}$ diam. Chlorite is mostly 
interstitial. Some grains very fresh, some have chlorite alteration of plag and pyroxene. Two grains of plag laths enclosed in red-black opaque glass; a few grains finer grained without subophitic texture. No 01. Prehnite and epidote which appeared in XRD pattern do not appear in this hand-picked sample.

8600-8610 Largely basalt, $80 \%$ Type I with traces of o1, groundmass with abundant hematite. Rest is Type II. One percent total calcite crystals, serpentinized ol crystals, zeolite, clay-filled amygdules, claystone, and devitrified tuff (locally spherulitic).

8670-8680 Forty percent devitrified silicic tuff llocally developed welding?); 40\% Type I basalt with abundant clay. Minor palagonite and skeletal opaques in the groundmass, 15\%, carbonate-rich claystone. Rest is Type II and III basalt.

8750-8760 Coarsely devitrified tuff, some plumose devitrification. Original (XRF) texture obliterated. Green clay and carbonate replacement of feldspars extensive in some grains. Sparse phenocrysts. Rare quartz phenocrysts with secondary bi-pyramidal overgrowths and chlorite pseudomorphs after pyroxene. Opaques sparse and sharply euhedral (cubic).

8800-8810 Medium to finely devitrified tuff. Some perlitic cracks still (XRF) apparent. Some plumose devitrification. Fairly homogeneous sample, strongly altered with extensive chlorite and calcite replacement of groundmass. Spray of prehnite(?) in one grain. Sparse phenocrysts of very altered plag. Sparse, usually small opaques, surrounded by rounded alteration rims.

8830-8840 Seventy-five percent basalt, (50\% Type II and 25\% Type I). Rest is claystone and devitrified silicic volcanic. Minor amounts of calcite, zeolite crystals, and palagonite.

8970-8980 Coarsely devitrified tuff, fairly homogeneous sample. Groundmass (XRF) contains some clay. Chlorite occurs in the groundmass and fills voids. Small carbonate veins occur in a few grains. Phenocrysts $\leq 10 \%$ of the rock and are extremely altered. Plag contains abundant opaque spots, small clusters of epidote crystals and clear patches of albite. The single pyroxene has been altered to chlorite. Sparse opaques appear resorbed and embayed. Sphene is associated with some opaques. 
9060-9070 Sixty percent devitrified silicic volcanic with relict plag crystals and pseudomorphs of chlorite after $\operatorname{cpx}($ ?) or ol(?); locally strongly spherulitic with abundant clay in the groundmass; $30 \%$ Type II basalt, $5 \%$ Type I basalt with minor 01 and green clay in groundmass. Minor claystone, clay-filled amygdules, and cataclastic basalt.

9110-9120 Subequal amounts of Type I and II basalts. Abundant calcite amygdules and veins of calcite, quartz, and epidote. Minor amounts of cataclastic basalt, claystone, and devitrified silicic volcanic.

9130-9150 Coarse-grained altered basalt. Opaques comprise 5-7\% of the rock (XRF) and are ilmenite and blocky and skeletal magnetite. Grey-green al teration of groundmass, epidote and minor calcite replacement in plag, some chlorite after pyroxene. Some epidote in the groundmass. Fragment of chlorite and prehnite vein or amygdule (with some epidote?).

9220-9250 Homogeneous sample of fine-grained $(\leq 0.25 \mathrm{~mm}$ long) $\mathrm{plag}$ in altered (XRF) and nearly opaque glassy matrix. Opaques barely discernible, include blocky magnetite and ilmenite. Epidote filling voids. Fragments of fracture filling quartz \pm epidote. Strained extinction in granular vein quartz.

9380-9390 Subequal amounts of devitrified silicic volcanic llocally spherulitic with abundant groundmass epidote) and largely Type I basalt. Ten percent of the basalt is unaltered, subophitic, and cpx-plag phyric. Silicic volcanic contains relict feldspar phenocrysts, and pseudomorphs of chlorite after cpx and ol(?).

9420-9460 Coarsely devitrified tuff, altered(?) dark brown. Some lighter (XRF) brown spherulites. Original textures obliterated. Chlorite is minor and occurs mostly as void and fracture fillings. Phenocrysts $\leq 10 \%$. Plag contains many tiny elongate opaques, perhaps the result of exclusion of opaque matter along cleavage planes on recrystallization. Small patches of green clay replacement and small clear albite(?) patches occur in plag. Some phenocrysts appear resorbed. Sparse opaques rounded and resorbed. Sparse chlorite pseudomorphs after pyroxene(?).

9500-9510 Ninety-five percent devitrified silicic volcanic (as above) with relict plag phenocrysts. Five percent Type I and Type II basalts. 
9590-9600 Seventy percent devitrified silicic volcanic, 30\% basalt (all three types). Minor claystone.

9676 (TD) Some variation in devitrification grain size, but mostly finely (XRF) devitrified. Faint relict perlitic cracks, both concentric and random outlined with chlorite. Patchy chlorite and epidote widespread throughout the groundmass. Phenocrysts $>10 \%$. Plag virtually undistinguishable in plane light because of recrystallization to albite with abundant opaque exclusions. Minor epidote in plag. Opaques are rounded. A cluster of small quartz may be recrystallized from larger grain.

\section{REFERENCES}

Belluomini, S. G. and G. Van Houten, "Petrographic and Stratigraphic Correlation of the Bostic 1A Well," Harding-Lawson Associates report to Los Alamos National Laboratory (1981).

APPENDIX C

CHEMICAL ANALYSES AND $X$-RAY DIFFRACTION DATA

TABLE C-I

CHEMICAL ANALYSES OF SELECTED ${ }^{a}$ BASALT SAMPLES FROM THE BOSTIC 1 -A WELL

\begin{tabular}{|c|c|c|c|c|c|c|c|c|}
\hline $\begin{array}{l}4450- \\
4470 \\
\mathrm{ft}\end{array}$ & $\begin{array}{l}5880- \\
5900 \\
\mathrm{ft}\end{array}$ & $\begin{array}{c}6220- \\
6230 \\
\mathrm{ft}\end{array}$ & $\begin{array}{c}6750- \\
6760 \\
\mathrm{ft}\end{array}$ & $\begin{array}{l}7790- \\
7800 \\
\mathrm{ft}\end{array}$ & $\begin{array}{c}\text { (Dike?) } \\
8050- \\
8060 \\
\mathrm{ft}\end{array}$ & $\begin{array}{c}8530- \\
8540 \\
\mathrm{ft}\end{array}$ & $\begin{array}{c}9130- \\
9150 \\
\mathrm{ft}\end{array}$ & $\begin{array}{l}\text { Dike } \\
9230- \\
9250 \\
\mathrm{ft}\end{array}$ \\
\hline 46.00 & 45.59 & 45.00 & 45.24 & 46.67 & 45.62 & 48.13 & 48.89 & 44.06 \\
\hline 3.48 & 3.09 & 2.81 & 2.65 & 2.06 & 2.51 & 1.88 & 3.13 & 3.61 \\
\hline 13.29 & 13.45 & 14.42 & 14.79 & 13.98 & 13.65 & 14.47 & 13.29 & 13.21 \\
\hline 15.06 & 12.77 & 13.63 & 12.64 & 11.60 & 12.02 & 11.04 & 13.02 & 14.83 \\
\hline 6.47 & 6.37 & 6.87 & 5.25 & 6.74 & 8.04 & 7.31 & 4.69 & 5.97 \\
\hline 0.23 & 0.20 & 0.23 & 0.18 & 0.19 & 0.21 & 0.19 & 0.20 & 0.23 \\
\hline 8.90 & 9.37 & 9.42 & 10.45 & 9.64 & 11.20 & 9.17 & 6.27 & 9.46 \\
\hline 2.22 & 2.62 & 2.50 & 1.53 & 3.11 & 2.08 & 2.95 & 3.04 & 1.95 \\
\hline 0.67 & 0.41 & 0.38 & 0.26 & 0.39 & 0.14 & 0.54 & 1.96 & 0.74 \\
\hline 0.72 & 0.75 & 0.56 & 0.38 & 0.34 & 0.40 & 0.33 & 0.63 & 0.71 \\
\hline 97.04 & 94.62 & 95.82 & 93.37 & 94.72 & 95.87 & 96.01 & 95.12 & 94.77 \\
\hline
\end{tabular}

\footnotetext{
a See text for discussion of selection criteria.

b Totals are believed low because of water contained in alteration minerals. Loss on ignition performed in air results in gains due to oxidation of iron, so actual water content has not been determined.
} 


\section{APPENDIX C (cont)}

\section{TABLE C-I I}

CHEMICAL ANALYSES OF SELECTED ${ }^{a}$ SAMPLES OF IDAVADA FROM THE BOSTIC 1-A WELL

\begin{tabular}{|c|c|c|c|c|c|c|c|}
\hline & $\begin{array}{c}7210- \\
7220 \\
\mathrm{ft}\end{array}$ & $\begin{array}{c}8250- \\
8270 \\
f t\end{array}$ & $\begin{array}{l}8750- \\
8760 \\
\mathrm{ft}\end{array}$ & $\begin{array}{l}8800- \\
8810 \\
\mathrm{ft}\end{array}$ & $\begin{array}{c}8970- \\
8980 \\
\mathrm{ft}\end{array}$ & $\begin{array}{c}9440- \\
9460 \\
\mathrm{ft}\end{array}$ & $\begin{array}{c}9676 \\
\text { (TD) } \\
\mathrm{ft}\end{array}$ \\
\hline $\mathrm{SiO}_{2}$ & 72.61 & 68.05 & 73.49 & 69.11 & 72.44 & 71.93 & 73.22 \\
\hline $\mathrm{TiO}_{2}$ & 0.55 & 0.71 & 0.41 & 0.59 & 0.50 & 0.56 & 0.50 \\
\hline $\mathrm{Al}_{2} \mathrm{O}_{3}$ & 12.04 & 13.73 & 11.36 & 13.14 & 12.11 & 11.67 & 11.81 \\
\hline $\mathrm{Fe} 0$ & 2.79 & 3.84 & 2.61 & 3.71 & 3.51 & 3.31 & 3.04 \\
\hline $\mathrm{MgO}$ & 0.35 & 0.72 & 0.34 & 0.91 & 0.37 & 0.46 & 0.30 \\
\hline Mno & 0.04 & 0.07 & 0.04 & 0.06 & 0.06 & 0.05 & 0.05 \\
\hline $\mathrm{CaO}$ & 1.03 & 2.33 & 1.21 & 2.56 & 1.14 & 1.25 & 1.56 \\
\hline $\mathrm{Na}_{2} \mathrm{O}$ & 2.79 & 2. 90 & 1.82 & 4.49 & 2.37 & 2.18 & 2.89 \\
\hline $\mathrm{K}_{2} \mathrm{O}$ & 5.34 & 4.23 & 5.74 & 1.87 & 5.40 & 5.86 & 4. 34 \\
\hline $\mathrm{P}_{2} \mathrm{O}_{5}$ & 0.06 & 0.11 & 0.05 & 0.06 & 0.05 & 0.05 & 0.06 \\
\hline LOI & 0.75 & 2.17 & 1.36 & 2.51 & 2.47 & 0.79 & 0.82 \\
\hline Total & 98.35 & 98.86 & 98.43 & 99.01 & 100.42 & 98.11 & 98.59 \\
\hline
\end{tabular}

$\bar{a}$ See text for discussion of selection criteria. 


\section{APPENDIX $C$ (cont) \\ TABLE C-III}

ALTERATION MINERALS DETERMINED BY XRD OF SELECTED UNITS
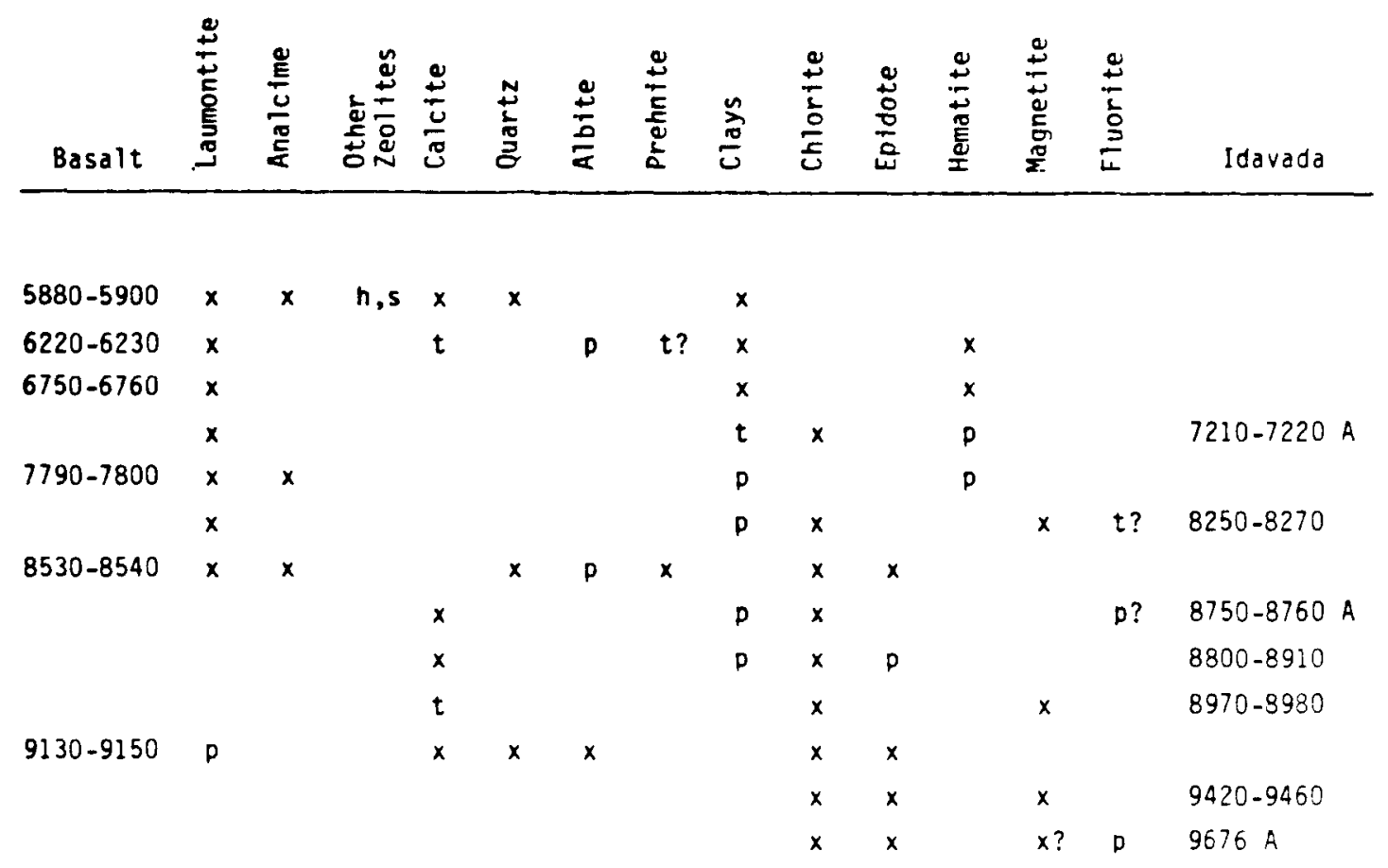


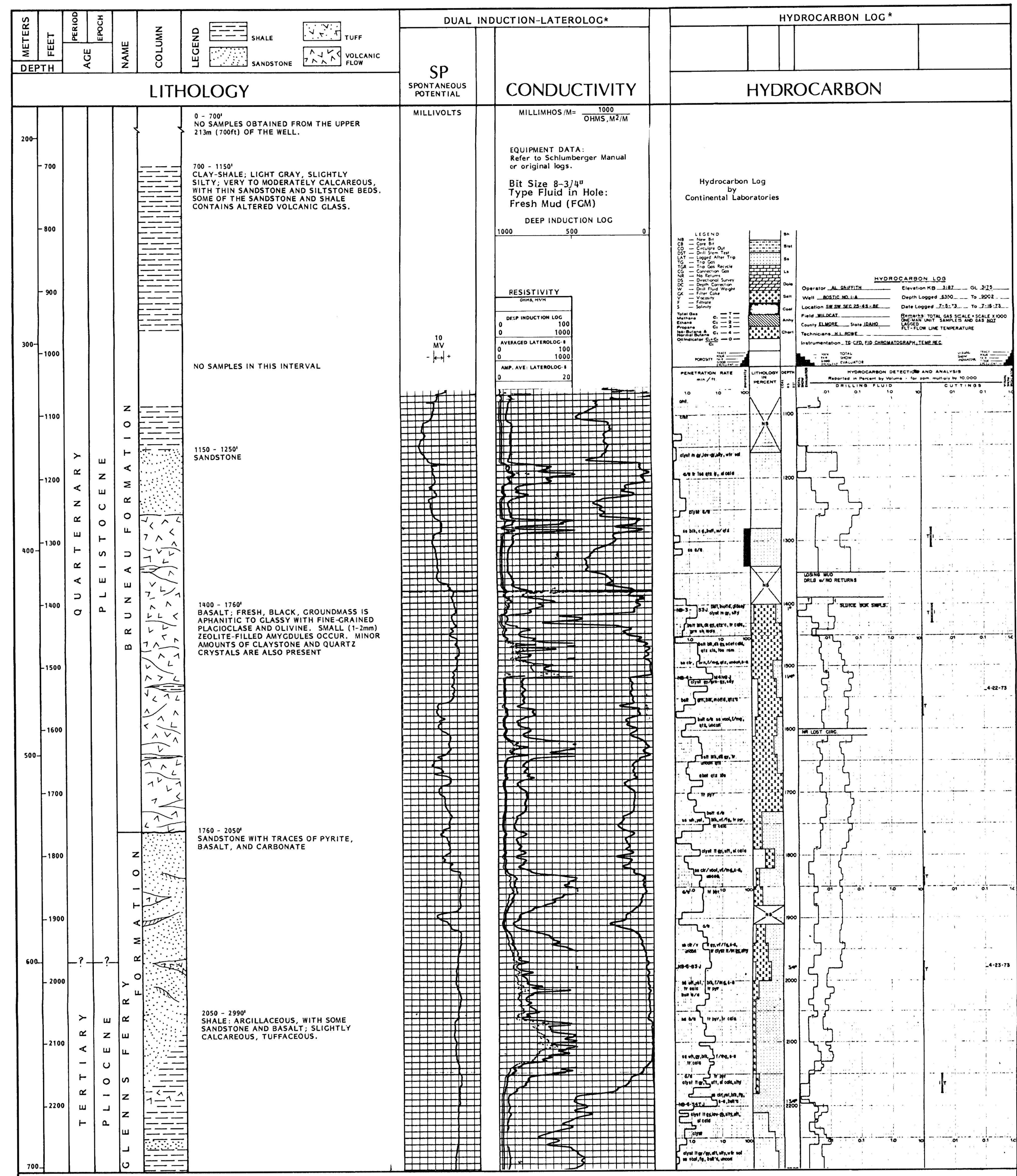

* Al Griffith, May-July 1973

** Culf Mineral Resources Co.,September 1974

Fig. A-1

Lithologic and geophysical logs of the Bostic 1-A well, Idaho (from Belluomini and Van Houten 1981). 


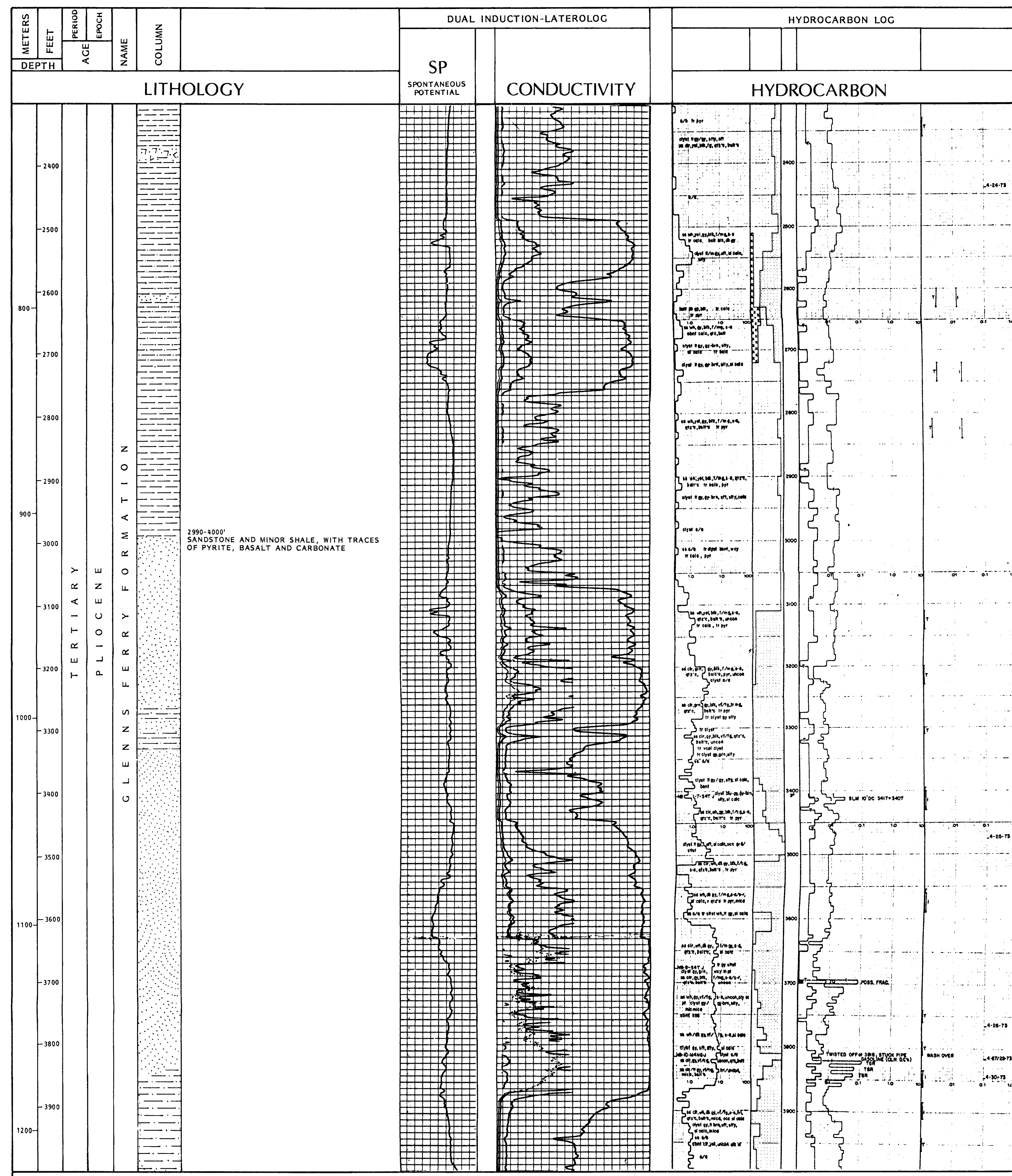

(b) 


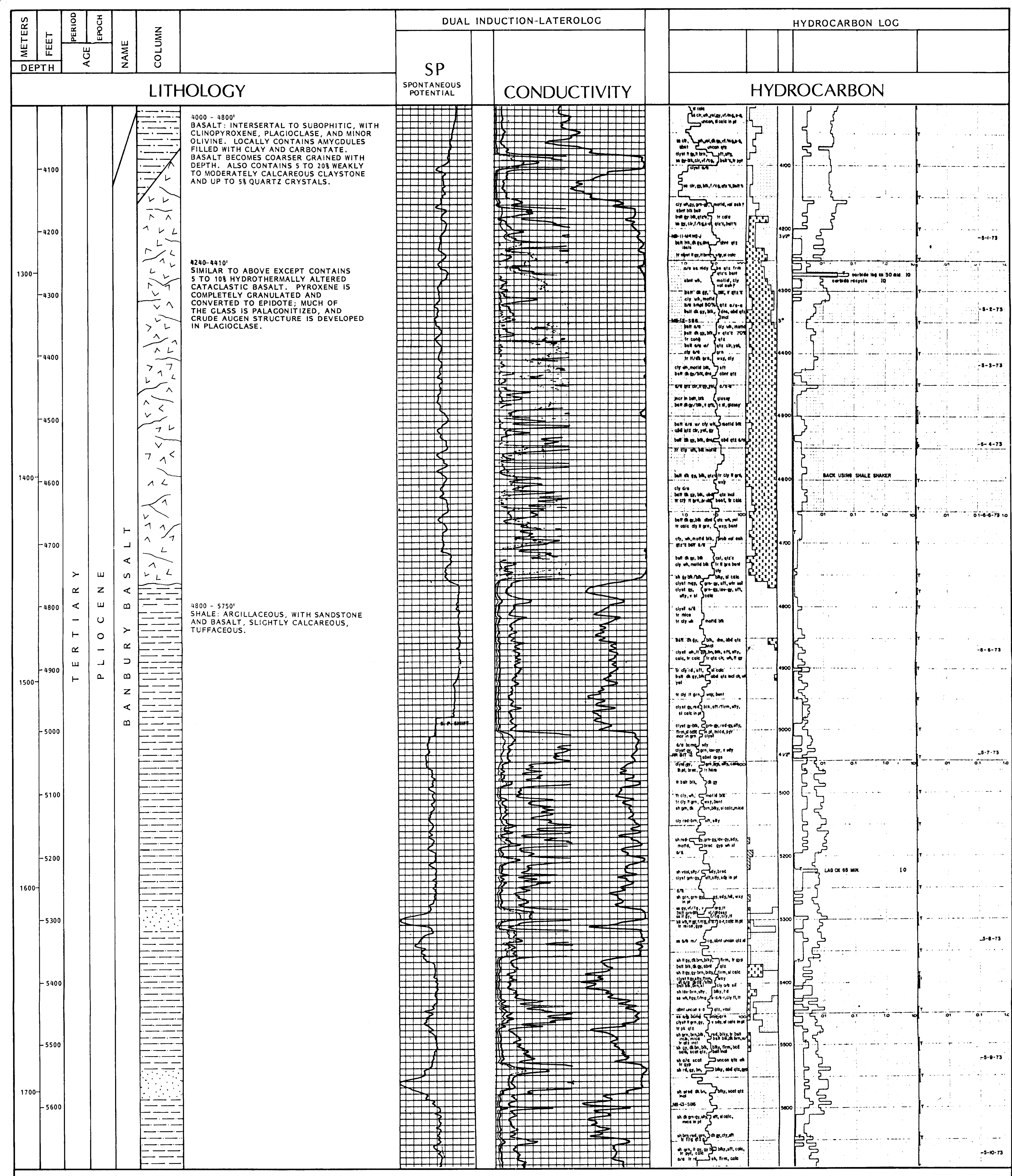




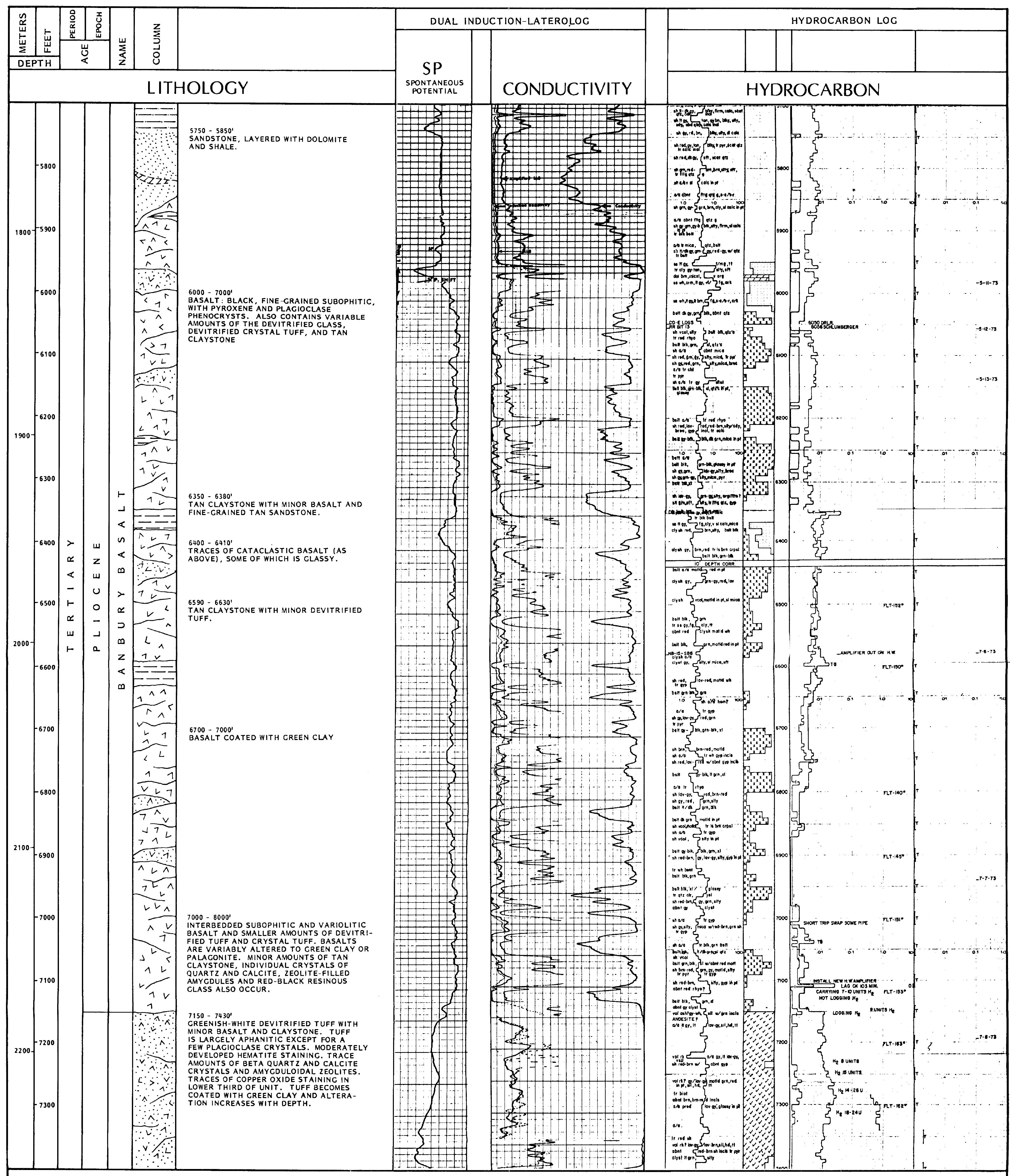




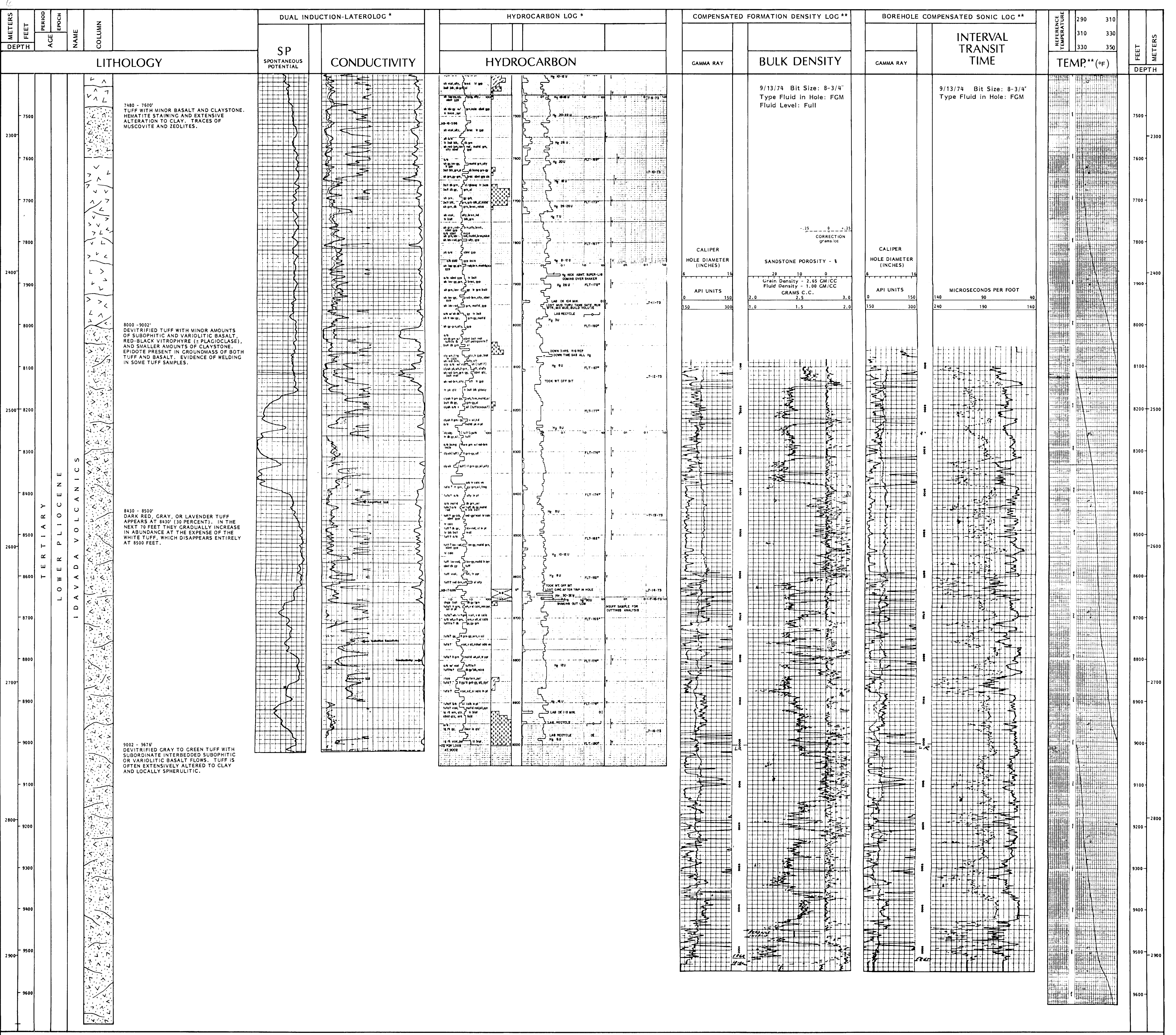

